\title{
Evaluation of Energy Properties of Mixed Biomass Charcoal Derived from Coconut, Palmyra Palm Nuts and Doum Palm Nuts Shells
}

\author{
Damgou Mani Kongnine ${ }^{1}$, Pali Kpelou ${ }^{1, ~}{ }^{*}$, N'Gissa Attah ${ }^{1}$, Essowè Mouzou ${ }^{2}$ \\ ${ }^{1}$ Department of Physics, Laboratoire Sur l'Energie Solaire, Université de Lomé, Lomé, Togo \\ ${ }^{2}$ Department of Physics, Laboratoire de Physique des Matériaux et des Composants à Semi-Conducteurs, Université de Lomé, Lomé, Togo
}

Email address:

kongnine@gmail.com (D. M. Kongnine), palikpelou@gmail.com (P. Kpelou)

*Corresponding author

\section{To cite this article:}

Damgou Mani Kongnine, Pali Kpelou, N'Gissa Attah, Essowè Mouzou. Evaluation of Energy Properties of Mixed Biomass Charcoal Derived from Coconut, Palmyra Palm Nuts and Doum Palm Nuts Shells. Science Journal of Energy Engineering. Vol. 9, No. 2, 2021 , pp. $17-21$. doi: $10.11648 /$ j.sjee.20210902.11

Received: May 6, 2021; Accepted: May 27, 2021; Published: June 4, 2021

\begin{abstract}
Organic waste generally has low calorific value. Thus, an energy densification procedure is necessary before their use as fuel. Studies have shown that the calorific value of the mixture of charcoals can be higher than the calorific value of the isolated constituents. The aim of this study was to investigate the energy potential of the charcoals produced from coconut shells (CS), palmyra palm nuts shells (PPS), doum palm nuts shells (DPS) and their mixtures in order to identify the rate of mixture allowing the improvement of their calorific value. The raw biomasses were carbonized in a homemade carbonizer. The charcoals obtained were ground into powder. Then samples of, pure biomass charcoals (CS100, PPS100, DPS100), double mixtures of 50\% of each biomass charcoals (CS50-PPS50, CS50-DPS50, PPS50-DPS50) and triple mixtures of (CS33-PPS33-DPS33, CS40-PPS30-DPS30, CS50-PPS25-DPS25, CS25-PPS50-DPS25, CS25-PPS25-DPS50) were made (the number corresponds to the content of each biomass charcoal in mass. Then, some of their energy parameters such as lower calorific value and energy per unit volume associated to bulk density were explored. The results showed that for pure samples, coconut shells charcoal presented the highest lower calorific value (28.059 MJ. kg $\left.{ }^{-1}\right)$, followed by charcoal $\left(27.054 \mathrm{MJ} / \mathrm{kg}\right.$ ), then doum palm nuts shells biochar $\left(26.929 \mathrm{MJ}^{-1} \mathrm{~kg}^{-1}\right)$ and finally $26.111 \mathrm{MJ}^{\mathrm{kg}} \mathrm{g}^{-1}$ for palmyra palm nuts shells charcoal. Similarly, with the highest bulk density of $0.625 \mathrm{~g} / \mathrm{cm}^{3}$ coconut shells charcoal presented the highest energy per unit volume $\left(17536.880 \mathrm{~J} / \mathrm{cm}^{3}\right)$, whereas with the lowest bulk density of 0.415 $\mathrm{g} / \mathrm{cm}^{3}$, doum palm nuts shells charcoal presented the lowest energy per unit volume. Coconut shells biomass charcoal energy per volume unit was significantly higher than that of charcoal used as control $\left(13905.760 \mathrm{~J} / \mathrm{cm}^{3}\right)$. For samples made up of mixtures, the lower calorific values obtained were lower than that of the most energetic pure biomass charcoal. Moreover, by comparing these measurements with the weighted average values of the calorific value of the mixtures, only the samples CS50-PPS25-DPS25 $(27.623 \mathrm{MJ} / \mathrm{kg})$ and CS40-PPS30-DPS30 $(27.583 \mathrm{MJ} / \mathrm{kg})$ showed an increase of the calorific value, higher than that of wood charcoal bought in the local market and used as reference $(27.054 \mathrm{MJ} / \mathrm{kg})$. However, for the others compositions, a decrease in calorific value was recorded.
\end{abstract}

Keywords: Biomass, Charcoal, Carbonization, Biomass Charcoal, Calorific Value, Heat per Volume Unit, Alternative Fuels

\section{Introduction}

World's population increase has led to an over consumption of fossils energies which not only run out in the short term, but also contribute to greenhouse gases emission. In the context of sustainable development, an energy transition towards low carbon renewable energies is essential. Among the sources of renewable energy, biomass is the oldest and most used today especially for cooking in southern countries $[1,2]$.

Biomass refers to the biodegradable part of plants and animals as well as biodegradable waste and residues. For energy production, biomass includes all organic matter derived from plant or animal that can be converted to energy. Several studies were focus on the energy recovery of 
biodegradable residues [3-7]. Also for the search for alternative fuels, many researchers depend on their localization have evaluated the energy potential of certain local agricultural wastes depending on their availability in the region [7-12]. Others studies were focused on the optimal carbonization of these residues and agglomeration of biomass charcoals briquettes using organic or mineral binders [13-15] Whether in the field of metallurgy [16-18] or in cogeneration [19] many researchers are interested in the production of biofuels from these residues [20]. By energetically upgrading corn cobs, Rafiq et al. [21] have shown that the yield of charcoal decreases as the carbonization temperature increases Their study has also shown that the physicochemical properties as well as the structural characteristics of the charcoal are significantly influenced by the pyrolysis temperature. Han et al. [22] studies showed that in order to obtain, during the carbonization of the stalks of corn and cotton, a charcoal of better combustibility, the final temperature must be between $300^{\circ} \mathrm{C}$ to $500^{\circ} \mathrm{C}$. Investing the potential of coconut shells as a biofuel, Yerima and Grema [23] concluded that it is essential and necessary to encourage the use of coconut shells as a domestic fuel, particularly in the rural areas of developing countries.

However, the utilization of organic wastes as fuel is not without risks. Some of them may contain toxic elements. In fact, Mani et al. [24] have evaluated some combustion characteristics of biomass charcoals produced from coconut husks, corn cobs and palm kernel shells. Their work showed the presence of chloride and sulfur in the ash of charcoal from corn cobs and green coconut peels. Among the studied charcoals, palm kernel shells charcoal seems to be the best candidate as alternative fuel in replacement of wood charcoal due to its relatively high calorific value associated to its chlorine and sulfur free-content. Thus, the carbonization step can not only reduce the risks of toxic elements but also concentrate the energy density.

Many recent researches were focused on the energy potential of some tropical nuts shells such us coconut shells, palm nuts shells and doum palm nuts shells biomass charcoal and briquettes issued from organic wastes used as energy source [25-27]. Despite their potential as energy sources, some combustion properties of these wastes, such as their moisture content, their ash content, their lower calorific value and their energy density may limit their use on a large scale.

One approach to remedy the low calorific value is to mix properly charcoal from different biomasses. Indeed, studies have shown that following well-proportioned mixtures of biomass charcoal, the calorific value has increased [28, 29].

The aim of the present study was the investigation of some combustion properties of the double and triple mixtures of charcoals from coconut shells, palm nuts shells and doum palm nuts shells in order to identify the suitable mixture for sustainable energy production. The scope of work included the determination of moisture content, bulk density, calorific value, and heat per volume unit as well as the influence of the ratio of biomass charcoal type on the calorific value of mixed charcoal. The goal of this study was to develop a multi-mixture nuts shells biomass charcoal order to make it as competitive as wood charcoal, and reduce wood charcoal utilization as energy source.

\section{Material and Methods}

All tested raw wastes used in this work were collected in the Republic of Togo (West Africa). Coconut shells (CS) were collected from small oil mills in Hahotoe (Togo). The remains of palmyra palm nuts shells (PPS) were collected from farmers in the Savannah region (Dapaong) after germination of fruits. The samples of the doum palm nuts shells (DPS) were obtained from Kara city and its surroundings. The palm doum shells were collected after pulp extraction. The wood charcoal used in this work as control, was bought in a local market.

The raw biomasses materials were first sun dried to constant mass and then carbonized in a homemade metallic carbonizer. The carbonization temperature was recorded using a k-type thermocouple. The obtained biomass charcoals were carried out from the carbonizer at final temperature between $280^{\circ} \mathrm{C}$ and $590^{\circ} \mathrm{C}$.

The obtained charcoals were crushed and sieved into fine powder. All the samples were made with the obtained powder. Then some combustion characteristics such as moisture content, bulk density and lower calorific value were evaluated using the same methodology as describe elsewhere [7].

The biomass charcoals powders obtained were also combined in double in a ratio of $50 \%-50 \%$ and in triple in ratios of 33\%-33\%-33\%, 50\%-25\%-25\% and 40\%-30\%-30\%. The double and triple combinations concerned only the coconut shells, palm nuts shells and doum palm shells. Using the same method as above, the lower calorific value of 8 samples resulting from mixing of specified proportion of biomass charcoals powder were determined.

\section{Results and Discussion}

Figure 1 represents photographs of raw biomasses and their corresponding charcoal used in this work.

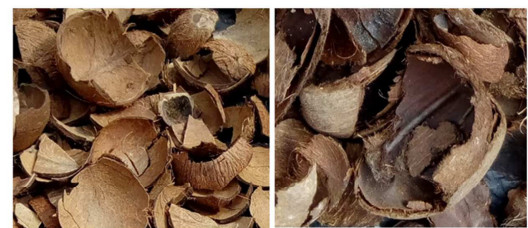

(a)

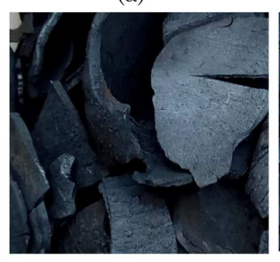

(d) (b)

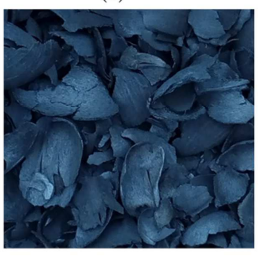

(e)

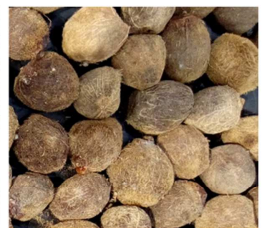

(c)

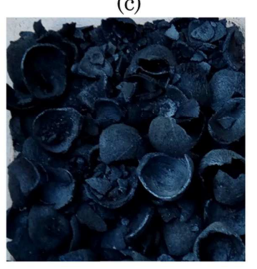

(f)
Figure 1. Photographs of raw biomasses samples: coconut shells (a); palmyra palm nuts shells (b); Doum Palm nuts Shells (c); their correspondent charcoals (d); (e); (f) [7]. 
Table 1 presents the parameters from proximate analysis, such us lower calorific value (LCV), moisture content (MC), bulk density (BD) and heat per volume unit (HPVU) of the studied charcoals.

The results showed that coconuts shells charcoal presented the highest lower calorific value $(28.059 \mathrm{MJ} / \mathrm{kg}$ ) followed by wood charcoal $(27.054 \mathrm{MJ} / \mathrm{kg})$, then doum palm nuts shells $(26.929 \mathrm{MJ} / \mathrm{kg})$ and finally palmyra palm nuts shells $(26.111$ $\mathrm{MJ} / \mathrm{kg}$ ) [7]. All those pure biomass charcoal could be used as alternative fuels in replacement of wood charcoal.

The results of the analysis showed that among the three pure biomasses charcoals samples studied, PPS showed the highest moisture content (5.24\%) followed by CS (4.55\%) and lowest value was recorded for DPS charcoal $(4.52 \%)$. The moisture content reported for wood charcoal used as control was almost two times higher than that of the three biomasses charcoals (9.2\%). The moisture content of charcoals used in this work were greater than the standard limit for suitable combustibles [30]. The relative high moisture content recorded for the three pure biomass charcoals and the very high value reported for wood charcoal could be due to the bad protection of charcoals against taking moisture from the air during storage. The moisture absorption of charcoal from the atmosphere is rapid even for well protected charcoal [31].

Table 1. Energy parameters of the studied pure biomass charcoal samples.

\begin{tabular}{|c|c|c|c|c|c|}
\hline Charcoals & MC (\%) & HCV (MJ. kg $\left.{ }^{-1}\right)$ & LCV (MJ. kg-1) & $\mathrm{BD}\left(\mathrm{g} / \mathrm{cm}^{3}\right)$ & HPVU $\left(J / \mathrm{cm}^{3}\right)$ \\
\hline CS100 & 4.55 & 28.622 & 28.059 & 0.625 & 17536.880 \\
\hline PPS100 & 5.24 & 26.691 & 26.111 & 0.492 & 12846.610 \\
\hline DPS100 & 4.52 & 27.491 & 26.929 & 0.415 & 11175.540 \\
\hline Charcoal & 9.72 & 27.747 & 27.054 & 0.514 & 13905.760 \\
\hline
\end{tabular}

Coconut shells biomass charcoal presented the highest density $\left(0.625 \mathrm{~g} / \mathrm{cm}^{3}\right)$, followed by palmyra palm nuts shells $\left(0.492 \mathrm{~g} / \mathrm{cm}^{3}\right)$ and the lowest value was recorded for doum palm nuts shells biomass charcoal $\left(0.415 \mathrm{~g} / \mathrm{cm}^{3}\right)$. Among the three biomasses charcoals studied in the present work only coconut shells charcoal showed a density slightly higher than that of wood charcoal.

Table 2 presents Moisture Content (MC), Lower Calorific Values (LCV) of double and triple mixture of biomasses charcoals.

The moisture content of the mixed biomass charcoal ranged from $4.77 \%$ for CS50-DPS50 and PPS50-DPS50 to $5.81 \%$ for CS25-PPS50-DPS25 are all lower than that of the wood charcoal.

Among the double charcoals mixture, the high LCV were

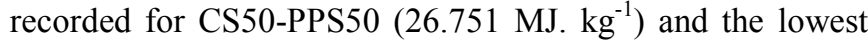
LCV was reported for CS50-DPS50 sample. For the triple mixture, the highest LCV was recorded for CS50-PPS25-DPS25 (27.623 MJ. kg $\left.{ }^{-1}\right)$ and the lowest value was obtained for CS25-PPS25-DPS50 sample. It is important to note that, for triple mixture, the samples with high coconut shells content resulted in high LCV value. The lower calorific value of mixtures CS50-PPS25-DPS25 (27.623 $\mathrm{MJ} / \mathrm{kg}$ ) and CS40-PPS30-DPS30 (27.583 MJ/kg) were higher than that of charcoal bought at the local market and used as control (27.054 MJ/kg).

Table 2. Energy parameters of the studied mixed biomass charcoal samples.

\begin{tabular}{|c|c|c|c|c|c|}
\hline Charcoal type & MC (\%) & HCV (MJ. $\mathrm{kg}^{-1}$ ) & LCV (MJ. kg-1) & BD $\left(\mathrm{g} / \mathrm{cm}^{3}\right)$ & HPVU $\left(\mathrm{j} / \mathrm{cm}^{3}\right)$ \\
\hline CS50-PPS50 & 5.49 & 27.338 & 26.751 & 0.551 & 14739.801 \\
\hline CS50-DPS50 & 4.77 & 26.282 & 25.713 & 0.499 & 12830.787 \\
\hline PPS50-DPS50 & 4.77 & 26.908 & 26.339 & 0.450 & 11852.550 \\
\hline CS40-PPS30-DPS30 & 5.16 & 28.162 & 27.583 & 0.510 & 14067.330 \\
\hline CS50-PPS25-DPS25 & 5.69 & 28.214 & 27.623 & 0.524 & 14474.452 \\
\hline CS25-PPS50-DPS25 & 5.81 & 26.875 & 26.281 & 0.496 & 13035.376 \\
\hline
\end{tabular}

Table 3. Energy balance induced by mixing biomass charcoals.

\begin{tabular}{llll}
\hline Mixed Biomass charcoals & LCV obtained $\left(\mathbf{M J} . \mathbf{~ k g}^{-1}\right)$ & LCV Expected $\left(\mathbf{M J} \mathbf{~ k g}^{-\mathbf{1}}\right)$ & Energy balance $\left(\mathbf{k J} . \mathbf{~ k g}^{-\mathbf{1}}\right)$ \\
\hline CS50-PPS50 & 26.7510 & 27.0850 & -334.00 \\
CS50-DPS50 & 25.7130 & 27.4940 & -1781.00 \\
PPS50-DPS50 & 26.3390 & 26.5200 & -181.00 \\
CS33-PPS33-DPS33 & 26.5600 & 27.0330 & -473.00 \\
CS40-PPS30-DPS30 & 27.5830 & 27.1356 & +447.40 \\
CS50-PPS25-DPS25 & 27.6230 & 27.2895 & +333.50 \\
CS25-PPS50-DPS25 & 26.2810 & 26.8025 & -521.50 \\
CS25-PPS25-DPS50 & 26.1870 & 27.0070 & -820.00 \\
\hline
\end{tabular}

Table 3 presents the measured LCV, the weighted average LCV values and the gap between them. The results showed that the variation of LCV values as a function of charcoals' mixture was not linear. The evaluation of this gap reveals that there are some mixtures that decreased the LCV while others enhanced it. The mixtures of CS40-PPS30-DPS30 and CS50PPS25-DPS25 presented an additional energy increase of $447.4 \mathrm{~kJ} / \mathrm{kg}$ and $333.5 \mathrm{~kJ} / \mathrm{kg}$ respectively. This result was comparable with that of Arellano et al. [29] who showed that the briquettes resulting from mixture of $50 \%$ in weight of 
coconut shell, $25 \%$ of sugarcane bagasse and $25 \%$ of corn cobs biomasses charcoals yield better heating values compared to its individual constituent. The combination of solid biofuels could therefore represent an excellent alternative for increasing their calorific value. However, attention should be paid to the ratio of elements in the mixture as it has been seen in this study (table 3 ).

For 6 of the 8 mixtures made, the difference between the measured value of the calorific value and its weight average is negative. This suggests that the combinations made are not appropriate for a higher energy value combustible.

Among these, mixtures CS50-DPS50 and CS25-PPS25-DPS50 showed the highest decrease, respectively of $1781.00 \mathrm{~kJ} / \mathrm{kg}$ and $820.00 \mathrm{~kJ} / \mathrm{kg}$.

\section{Conclusion}

This work focused on energy potential of three biomass charcoals mixture from some tropical fruits nuts shells residues such as coconut, palmyra palm nuts and doum palm nuts shells. Wood charcoal was used as control. Combinations with higher coconut shells content yielded higher calorific value. Coconut shells charcoal presented the highest calorific value. Among all mixtures, CS50-PPS25-DPS25 combination showed the highest calorific value for all muti-constituent mixtures.

The combination of solid biofuels is therefore an excellent alternative for increasing their calorific value. However, attention should be paid to the ratio of elements in the combination. As, it has been found in this study, there are some charcoals' mixtures which were destructive for calorific value.

Further studies are necessary to determine the optimum mixing ratio and the suitable binder to produce more efficient mixed charcoals briquettes.

\section{References}

[1] Jones MB, Kansiime F, Saunders MJ. The potential use of papyrus (Cyperus papyrus L.) wetlands as a source of biomass energy for sub-Saharan Africa. GCB Bioenergy. 2018.

[2] Brocard D, Lacaux JP, Eva H. Domestic biomass combustion and associated atmospheric emissions in West Africa. Global Biogeochem Cycles. 1998.

[3] Capareda S. - Biomass as Energy Source. In: Introduction to Biomass Energy Conversions. 2020.

[4] Kolat P, Kadlec Z. Sewage sludge as a biomass energy source. Acta Univ Agric Silvic Mendelianae Brun. 2013.

[5] Tîrtea R-N, Mărculescu C. Aspects of using biomass as energy source for power generation. Proc Int Conf Bus Excell. 2017.

[6] Lora ES, Andrade R V. Biomass as energy source in Brazil. Renewable and Sustainable Energy Reviews. 2009.

[7] Mani KD, Kpelou P, Attah N, Kombate S, Mouzou E, Djeteli G, et al. Energy resource of charcoals derived from some tropical fruits nuts shells. Int J Renew Energy Dev. 2020.
[8] Kpelou P, Kongnine DM, Kombate S, Mouzou E, Napo K. Energy Efficiency of Briquettes Derived from Three Agricultural Waste's Charcoal Using Two Organic Binders. J Sustain Bioenergy Syst. 2019.

[9] Verkerk PJ, Fitzgerald JB, Datta P, Dees M, Hengeveld GM, Lindner M, et al. Spatial distribution of the potential forest biomass availability in europe. For Ecosyst. 2019.

[10] Saghir M, Zafar S, Tahir A, Ouadi M, Siddique B, Hornung A. Unlocking the potential of biomass energy in Pakistan. Frontiers in Energy Research. 2019.

[11] Van Holsbeeck S, Brown M, Srivastava SK, Ghaffariyan MR. A review on the potential of forest biomass for bioenergy in Australia. Energies. 2020.

[12] Chen X. Economic potential of biomass supply from crop residues in China. Appl Energy. 2016.

[13] Zanella K, Concentino VO, Taranto OP. Influence of the type of mixture and concentration of different binders on the mechanical properties of "green" charcoal briquettes. Chem Eng Trans. 2017.

[14] Zubairu A, Gana SA. Production and Characterization of Briquette Charcoal by Carbonization of Agro-Waste. Energy and Power. 2014.

[15] Aransiola EF, Oyewusi TF, Osunbitan JA, Ogunjimi LAO. Effect of binder type, binder concentration and compacting pressure on some physical properties of carbonized corncob briquette. Energy Reports. 2019.

[16] Mousa EA, Babich A, Senk D, Metallurgy F, Aachen R. Iron Ore Sintering Process with Biomass Utilization. Cent Metall Res Dev Inst. 2015.

[17] Griessacher T, Antrekowitsch J. Biomass as reducing agent in the metallurgy. In: Proceedings - European Metallurgical Conference, EMC 2009. 2009.

[18] Pamungkas BC, Hadi H. Potential of Biomass Utilization in Rotary Kiln of Nickel Processing Plant. In: IOP Conference Series: Materials Science and Engineering. 2019.

[19] de Miranda RC, Bailis R, Vilela A de O. Cogenerating electricity from charcoaling: A promising new advanced technology. Energy Sustain Dev. 2013.

[20] Billaud J, Valin S, Peyrot M, Salvador S. Influence of H2O, $\mathrm{CO} 2$ and $\mathrm{O} 2$ addition on biomass gasification in entrained flow reactor conditions: Experiments and modelling. Fuel. 2016.

[21] Rafiq MK, Bachmann RT, Rafiq MT, Shang Z, Joseph S, Long RL. Influence of pyrolysis temperature on physico-chemical properties of corn stover (zea mays 1.) biochar and feasibility for carbon capture and energy balance. PLoS One. 2016.

[22] Han K, Wang Q, Zhao J, Luo KH, Li H, Chen Y, et al. Combustion pattern, characteristics, and kinetics of biomass and chars from segmented heating carbonization. Asia-Pacific J Chem Eng. 2016.

[23] Yerima I, Grema MZ. The Potential of Coconut Shell as Biofuel. J Middle East North Africa Sci. 2018.

[24] Damgou Mani Kongnine, Pali Kpelou, Komi Sodoga and KN. Evaluation of Some Combustion Characteristics of Biochar produced from Coconut Husks, Corn Cobs and Palm Kernel Shells. Int J Innov Appl Stud [Internet]. 2018; 24 (3): 1124-30. Available from: http://www.ijias.issr-journals.org/. 
[25] Chumsang C, Upan P. Production of Charcoal Briquettes from Palmyra Palm Waste in Kirimat District, Sukhothai Province, Thailand. Appl Environ Res. 2014.

[26] Yerizam M, Faizal. M F., Marsi M, Novia N. Characteristics of Composite Rice Straw and Coconut Shell as Biomass Energy Resources (Briquette)(Case study: Muara Telang Village, Banyuasin of South Sumatra). Int J Adv Sci Eng Inf Technol. 2013.

[27] Aremu AK, Fadele OK. Moisture Dependent Thermal Properties of Doum Palm Fruit (Hyphaene Thebaica). J Emerg Trends Eng Appl Sci. 2010.

[28] Mani KD, Kpelou P, Baneto M, Napo K. Calorific Value
Enhancement due to Combination of Biochars from Corn cobs, Tender Coconut Husks and Palm Kernel Shells. Int J Adv Res. 2018.

[29] Arellano GMT, Kato YS, Bacani FT. Evaluation of Fuel Properties of Charcoal Briquettes Derived From Combinations of Coconut Shell, Corn Cob and Sugarcane Bagasse. DLSU Res Congr 2015. 2015.

[30] FAO, 1983, 41 Techniques simples de carbonisation.

[31] Kymäläinen M, Mäkelä MR, Hildén K, Kukkonen J. Fungal colonisation and moisture uptake of torrefied wood, charcoal, and thermally treated pellets during storage. Eur J Wood Wood Prod. 2015. 